\title{
Implementasi Model Pembelajaran Kooperatif Dengan Menggunakan Strategi Murder (Mood, Understand,Recall, Digest, Expand, Review) Untuk Meningkatkan Hasil Belajar Siswa Kelas $X$ TKJ SMK Negeri 4 Gowa
}

\author{
Dira Kartika Sari \\ Pendidikan Teknik Informatika dan Komputer, Universitas Negeri Makassar. \\ dirakartika.sari@yahoo.co.id
}

\begin{abstract}
Abstrak - Penelitian ini bertujuan (a) untuk mengetahui persentase ketuntasan siswa dalam peningkatan hasil belajar siswa pada mata pelajaran dasar desain grafis dengan menggunakan strategi MURDER (Mood, Understand, Recall, Digest, Expand, Review) pada siswa kelas X TKJ SMK Negeri 4 Gowa (b) untuk mengetahui peningkatan hasil belajar dasar desain grafis melalui implementasi strategi MURDER (mood, understand, recall, digest, expand, review) pada siswa kelas X TKJ SMK Negeri 4 Gowa. Jenis penelitian yang digunakan dalam penelitian ini adalah penelitian tindakan kelas (classroom action research). Penelitian ini dilaksanakan sebanyak dua Siklus. Setiap siklus dilaksanakan dengan 3 kali pertemuan menggunakan prosedur tindakan yaitu perencanaan, pelaksanaan tindakan, pengamatan, dan refleksi. Pengambilan data melalui tes, observasi dan dokumentasi. Subjek dari penelitian ini adalah siswa kelas X TKJ. Data yang terkumpul kemudian dianalisis menggunakan analisis statistik deskriptif. Berdasarkan hasil penelitian (a) presentase dari Siklus I nilai ketuntasan siswa sebesar 73,3\% atau sekitar 22 siswa dan Siklus II sebesar 93,3\% atau sekitar 28 siswa, dari data hasil belajar tersebut dapat dilihat terjadi peningkatan secara berkala (b) implementase model pembelajaran kooperatif dengan menggunakan strategi MURDER (Mood, Understand, Recall, Digest, Expand, Review) ternyata dapat meningkatkan hasil belajar siswa kelas X TKJ di SMK Negeri 4 Gowa.
\end{abstract}

Kata Kunci: Model Pembelajaran, Kooperatif MURDER, Hasil Belajar.

\section{PENDAHULUAN}

Pendidikan adalah salah satu bentuk perwujudan kebudayaan manusia yang dinamis dan saraf perkembangan. Oleh karena itu, perubahan atau perkembangan pendidikan dalah hal yang memang seharusnya terjadi sejalan dengan perubahan budaya kehidupan. Perubahan dalam arti perbaikan pendidikanpada semua tingkat perlu terus menerus dilakukan sebagai antisipasi kepentingan masa depan. Ditambah pesatnya kemajuan teknologi membuat pembelajaran lebih inovatis- progresif. Hal ini dimaksudkan agar pendidikan dapat sejalan dengan perubahan budaya yang ada dalam kehidupan. (Eko, 2009: 25)

Pembelajaran merupakan suatu sistem instruksional yang mengacu pada seperangkat komponen yang saling bergantung satu sama lain untuk mencapai tujuan. Sebagai sebuah sistem, pembelajaran meliputi suatu komponen, dimana komponen pembelajaran tersebut akan mempengaruhi jalannya pembelajaran. Salah satu komponen penting yang harus diperhatikan secara terus menerus dalam proses pembelajaran adalah guru. Guru dalam konteks pendidikan mempunyai peranan yang besar dan strategis. Hal ini disebabkan karena guru menjadi "garda terdepan" dalam proses pelaksaan pendidikan. Guru adalah sosok yang langsung berhadapan dengan peserta didik dalam mentransformasi ilmu pengetahuan dan teknologi, sekaligus mendidik putra bangsa dengan nilai-nilai konstruktif. Untuk itu kualitas guru harus ditingkatkan terus menerus, seiring dengan perubahan tuntutan dan perubahan zaman. Dengan kata lain, di satu sisi kualitas pendidikan dapat ditingkatkan apabila guru memiliki kompetensi standar yang berkaitan dengan tugas dan tanggung jawabnya.

Salah satu tugas dan tanggung jawab guru adalah transfer of knowledge, yakni proses mentansfer ilmu pengetahuan, informasi, pengalaman dan pelajaran dari berbagai sumber kepada penerima. Dalam dunia pendidikan transfer of knowledge sangat bermanfaat untuk mencapai tujuan pendidikan yaitu untuk meningkatkan kemampuan dan ketrampilan siswa. Proses transfer knowledge akan berjalan dengan baik apabila terjalin komunikasi yang baik antara guru dan siswa. Guru menyampaikan pelajaran perlu mengamati kondisi siswa, kebutuhan siswa dan gaya belajar masing- masing siswa sehingga mampu menentukan model pembelajaran yang tepat dan menciptakan pembelajaran yang menyenangkan sesuai dengan kebutuhan siswa.(Deporter, 2008: 165)

Tetapi dalam kenyataannya banyak para subjek belajar ketika melakukan proses pembelajarann tidak menyertakan unsur- unsur pemahaman. Salah satu fenomena yang sering terjadi adalah, para siswa akan belajar pada malam hari menjelang ujian di pagi harinya. Kegiatan belajar yang demikian ini cenderung sekedar mengetahui sesuatu bahan pelajaran yang dituangkan di kertas ujian, tetapi kalau ditanya pada dua atau tiga hari kemudian, mengenai apa yang dipelajari ke dalam suatu konsep atau kegiatan secara menyeluruh mereka akan lupa dan harus mengulang untuk belajar kembali.

Upaya mengatasi permasalahan tersebut diperlukan suatu model pembelajaran yang bisa meningkatkan kemampuan hasil belajar kognitif siswa. Salah satu model yang menekankan kognitif dalam proses pembelajaran adalah pembelajaran strategi MURDER (Mood, Understand, Recall, Digest, Expand, Review) yaitu suatu model pembelajaran yang dihasilkan dari perspektif psikologi kognitif. Berdasarkan uraian permasalahan diatas peneliti ingin mengkaji lebih dalam mengenai implementasi model pembelajaran kooperatif dengan strategi MURDER pada mata pelajaran desain grafis di SMK Negeri 4 Gowa.

Berdasarkkan latar belakang di atas maka rumusan masalah pada penelitian ini adalah Berapakah persentase ketuntasan siswa dalam model pembelajaran kooperatif dengan strategi MURDER (Mood, Understand, Recall, Digest, Expand, Review) pada mata pelajaran dasar desain grafis siswa kelas X TKJ SMK Negeri 4 Gowa? Apakah melalui implementasi model pembelajaran dengan menggunakan strategi MURDER (Mood, Understand, Recall, Digest, Expand, Review) dapat meningkatkan hasil belajar dasar desain grafis siswa kelas X TKJ SMK Negeri 4 Gowa meningkat? 


\section{LANDASAN TEORI}

\section{A. Pengertian Model Pembelajaran}

Model pembelajaran merupakan suatu pendekatan dalam rangka mensiasati perubahan perilaku peserta didik secara adaptif maupun generatif. Model pembelajaran ialah suatu abstraksi yang dapat digunakan untuk membantu memahami sesuatu yang tidak bisa dilihat atau dialami secara langsung. Menurut Seel and Richey, model pembelajaran adalah representasi realitas yang disajikan dengan suatu derajat struktur dan urutan. (Amri, 2014 85) Kata dasar dari pembelajaran adalah belajar. Belajar merupakan proses perubahan diri seseorang. Pembelajaran adalah kegiatan yang dilakukan untuk menciptakan suasana belajar. Adapun pembelajaran tidak jauh dengan istilah pendidikan. Pembelajaran merupakan aktifitas guru dikelas yang terprogram yang bertujuan membuat siswa belajar secara aktif. Jika guru memahami proses bagaimana pengetahuan didapat, maka guru dapat menentukan strategi pembelajaran yang tepat bagi siswanya.

Model pembelajaran menurut Soekamto adalah kerangka konseptual yang melukiskan prosedur yang sistematis dalam mengorganisasikan pengalaman belajar untuk mencapai tujuan belajar tententu, berfungsi sebagai pedoman bagi para perancang pembelajaran dan para pengajar dalam merencanakan aktivitas belajar mengajar. Joyee dan Weil menyatakan bahwa "Models of teaching are really models of learning. As we help student acquire information, ideas, skills, value, ways of thingkig and means of expressing rhemselve, we are also teaching them how to learn." ini berarti model pembelajaran adalah model belajar, dengan models tersebut guru dapat membantu siswa untuk mendapatkan atau memperoleh informasi, ide, keterampilan, cara berikir, dan mengeksplor ide diri sendiri. (Trianto, 2010: 51)

B. Macam-Macam Model Pembelajaran Kooperatif

1. Think-Pair-Share

Model pembelajaran kooperatif tipe Think-Pair-Share merupakan salah satu model pembelajaran kooperatif yang mampu mengubah asumsi bahwa metode resitasi dan diskusi perlu diselenggarakan dalam setting kelompok kelas secara keseluruhan. Think-Pair-Share memiliki prosedur yang ditetapkan secara eksplisit untuk memberi siswa waktu yang lebih banyak untuk berpikir, menjawab, dan saling membantu satu sama lain. Dari cara seperti ini diharapkan siswa mampu bekerja sama, saling membutuhkan, dan saling tergantung pada kelompok-kelompok kecil secara kooperatif (Zaini, 2007).

\section{Problem Solving}

Problem solving (pembelajaran berbasis masalah) merupakan pendekatan pembelajaran yang menggiring siswa untuk dapat menyelesaikan masalah (problem). Masalah dapat diperoleh dari guru atau dari siswa. Dalam proses pembelajarannya siswa dilatih untuk kritis dan kreatif dalam memecahkan masalah serta difokuskan pada membangun struktur kognitif siswa (Aunurrahman, 2009).

\section{Team Games Tournament (TGT)}

Pada pembelajaran kooperatif tipe Team Games Tournament (TGT), peserta didik dikelompokkan dalam kelompok-kelompok kecil beranggotakan empat peserta didik yang masing-masing anggotanya melakukan turnamen pada kelompoknya masingmasing. Pemenang turnamen adalah peserta didik yang paling banyak menjawab soal dengan benar dalam waktu yang paling cepat (Siregar \& Nara, 2007).

\section{Kooperatif (CL, Cooperative Learning)}

Pembelajaran koperatif sesuai dengan fitrah manusia sebagai makhluk sosial yang penuh ketergantungan dengan orang lain, mempunyai tujuan dan tanggung jawab bersama, pembagian tugas, dan rasa senasib. Dengan memanfaatkan kenyatan itu, belajar berkelompok secara koperatif, siswa dilatih dan dibiasakan untuk saling berbagi (sharing) pengetahuan, pengalaman, tugas, tanggung jawab. Saling membantu dan berlatih beinteraksikomunikasi- sosialisasi karena koperatif adalah miniature dari hidup bermasyarakat, dan belajar menyadari kekurangan dan kelebihan masing-masing. Model pembelajaran koperatif adalah kegiatan pembelajaran dengan cara berkelompok untuk bekerja sama saling membantu mengkontruksi konsep, menyelesaikan persoalan, atau inkuiri. Menurut teori dan pengalaman agar kelompok kohesif (kompak-partisipatif), tiap anggota kelompok terdiri dari $4-5$ orang, siswa heterogen (kemampuan, gender, karekter), ada control dan fasilitasi, dan meminta tanggung jawab hasil kelompok berupa laporan atau presentasi.Sintaks pembelajaran koperatif adalah informasi, pengarahan-strategi, membentuk kelompok heterogen, kerja kelompok, presentasi hasil kelompok, dan pelaporan.

C. Model Pembelajaran Kooperatif MURDER

Pembelajaran kooperatif MURDER didasarkan atas teori perkembangan psikologi kognitif yang memiliki perspektif dominan dalam pendidikan masa kini yang terfokus pada bagaimana manusia memperoleh, menyimpan, dan memproses apa yang dipelajarinya, dan bagaimana proses berpikir dan belajar itu terjadi (Santyasa,2008). Pembelajaran kooperatif MURDER menekankan pentingnya kemampuan berbahasa atau keterampilan verbal siswa dalam mengulang dan merekontruksi informasi dan ide suatu materi pembelajaran, untuk dipahami dan dijadikan sebagai miliknya yang kemudian mampu kembali dikomunikasikan dengan baik secara verbal.

Model pembelajaran kooperatif MURDER menggunakan sepasang anggota dyad dari suatu kelompok yang beranggotakan 4 orang, dengan langkah kegiatan pembelajaran adalah sebagai berikut (Jacobs dalam Lestari, 2008).

1. Mood, mengatur suasana hati yang cocok dengan cara relaksasi dan berfokus pada tugas kelompok. Peran guru adalah berusaha memfasilitasi siswa pada situasi belajar yang memotivasi siswa untuk fokus pada kegiatan pembelajaran yaitu dengan cara memberikan informasi atau fenomenafenomena menarik dalam kehidupan sehari-hari.

2. Understand, membaca bagian materi tertentu dari naskah tanpa menghafalkan oleh masing-masing dyad dalam suatu kelompok. Peran guru adalah membagi naskah menjadi beberapa bagian sehingga memudahkan siswa dalam membagi tugasnya serta mengarahkan siswa untuk mencermati aspek penting yang ada pada naskah tersebut. Pada fase ini guru dapat menggunakan LKS untuk menunjang proses pembelajaran.

3. Recall, salah satu anggota kelompok memberikan sajian lisan dengan mengulang materi yang dibaca. Peran guru adalah memilih secara acak anggota dyad sehingga mendorong kesiapan dari setiap anggota dyad untuk menyajikan materi.

4. Digest (penelahaan), yaitu siswa dilatih untuk menemukan kesalahan kata yang sulit, kalimat, pargraph yang sulit sehingga diperlukan koreksi terhadap kesalahan yang muncul.

5. Expand, dilakukan oleh sesama pasangan. Setiap pasangan dapat memberikan contoh atau aplikasi materi yang telah dibaca dalam kehidupan sehari-hari, mengemukakan opini mereka terhadap topik yang dibahas ataupun mengemukakan beberapa pertanyaan yang terkait dengan topik yang dibahas. Langkah-langkah 2, 3, 4, 5 diulang untuk bagian materi selanjutnya.

6. Review atau merangkum kembali hasil pekerjaan berdasarkan hasil diskusi yang berlangsung dan menyimpulkan hasil 


\section{diskusi.}

Langkah-langkah digest, recall, dan expand dapat berhasil memperkuat pembelajaran karena pasangan dyad harus secara verbal mengemukaan, menjelaskan, memperluas dan mencatat ide-ide utama dari teks. Keterampilan memproses informasi lebih diutamakan karena menuntut keterlibatan metakognisi-berpikir dan membuat keputusan berdasarkan pemikiran dan perkembangan yang konsisten terhadap sistem operasi yang dimilikinya.

a. Jelly Bean (OS Android 4.1-4.3)

Tak berhenti sampai di situ, Android membuktikan eksistensinya lewat OS versi terbarunya yaitu Jelly Bean yang resmi dirilis bulan Juli tahun 2012. Dalam versi terbarunya ini, terdapat pembaharuan peningkatan input keyboard yang kian lengkap dan adanya pencarian Google Now yang mampu memberikan berbagai informasi mengenai cuaca dan traffic.

\section{b. Kitkat (OS Android 4.4+)}

OS ini mampu memberikan tampilan status bar transparan serta dapat beroperasi secara optimal pada perangkat berspesifikasi rendah. Dan juga pada saat perilisan OS ini, Android juga merilis Android Wear, yang mana dapat digunakan pada smartwaches.Selain itu Android juga memperbarui User Interface pada program Google Maps Navigation dan Alarms

\section{c. Lolipop (OS Android 5.+)}

Fitur-fitur pada Android Lollipop merupakan desain ulang dari user interface yang dibangun sekitar bahasa desain responsive yang disebut dengan"material design".Perubahan lainnya yaitu perbaikan pada pemberitahuan/notifikasi, yang bisa di akses dari lockscreen dan dapat ditampilkan tanpa aplikasi tambahan sebagai top-of-the- screen banner. Dan Google juga membuat suatu perubahan internal untuk platform, dengan Android Runtime (ART) yang secara resmi menggantikan Dalvik untuk meningkatkan performa aplikasi dan bermaksud juga untuk meningkatkan dan mengoptimalkan penggunaan baterai yang dikenal oleh mereka sebagai projek Volta.

\section{d. Marshmallow (Android 6.0+)}

Android 6.0 "Marshmallow" adalah lanjutan pengembangan dari Android Lollipop, OS ini diperkenalkan pada bulan Mei 2015 di Google I / O dengan codename "Android 'M' " dan resmi dirilis pada bulan Oktober 2015. Marshmallow berfokus untuk meningkatkan pengalaman dari pengguna Lollipop, dengan memperkenalkan arsitektur app permission yang baru, API baru untuk menyempurnakan asisten kontekstual dalam "Google Now On Tap" yang merupakan sebuah kemampuan baru dari aplikasi Google Search, lalu sebuah sistem (Doze) manajemen daya baru yang bisa mengurangi aktivitas pada background jika perangkat sedang tidak digunakan, kemudian dukungan asli untuk pengenalan sidik jari dan konektor USB tipe-C. Ditambah juga dengan kemampuan untuk migrasi data ke kartu microSD dan menggunakannya sebagai penyimpanan utama.

\section{METODE PENELITIAN}

\section{A. Jenis Penelitian}

Penelitian ini merupakan penelitian tindakan kelas (classroom action research) yang dilaksanakan secara bersiklus. Tindakan yang dilakukan pada setiap siklus bertujuan untuk meningkatkan hasil belajar siswa melalui Strategi MURDER yang melalui tahapan perencanaan, pelaksanaan tindakan, observasi dan observasi disetiap siklus.

Penelitian ini dilaksanakan pada semester ganjil dari bulan November s/d bulan Desember tahun ajaran 2018/2019 di SMK
Negeri 4 Gowa.

B. Prosedur Penelitian

Penelitian tindakan ini akan dilaksananakan dalam 2 siklus yaitu Siklus I dan Siklus II. Antara Siklus I dan Siklus II merupakan rangkaian kegiatan yang saling berkaitan dalam artian pelaksanaan Siklus II merupakan kelanjutan dan perbaikan dari Siklus I. adapun gambaran umum kegiatan yang akan dilaksanakan dalam tiap-tiap siklus penelitian dapat digambarkan sebagai berikut:

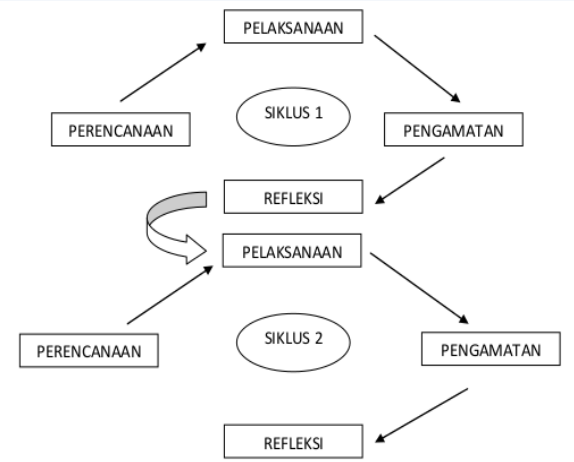

Gambar 1. Model Tahapan Penelitian Tindakan Kelas (Arikunto: 2010)

\section{Jenis Tindakan}

Penelitian tindakan kelas ini dilaksanakan pada semester ganjil tahun ajaran 2018/2019 yang direncanakan dalam dua siklus. Kedua siklus tersebut merupakan rangkaian yang saling berkaitan. Artinya, setiap siklus dilaksanakan berdasarkan siklus sebelumnya dengan mempelajari kekurangan pada siklus pertama. Dalam setiap siklus berlangsung selama 3 kali pertemuan, dan disetiap siklus pada pertemuan pertama sebelum pembelajaran dilakukan tes evaluasi begitu juga pada setiap akhir siklus dilakukan tes evaluasi, hal ini bertujuan untuk mengetahui perkembangan hasil belajar siswa setiap.

\section{HASIL PENELITIAN}

A. Prosedur dan Hasil Penelitian

Penelitian ini dilakukan untuk mengetahui peningkatan hasil belajar siswa menggunakan model pembelajaran kooperatif MURDER (Mood, Understand, Recall, Digest, Expand, Review) pada siswa kelas X TKJ-4 di SMK Negeri 4 Gowa. Penelitian ini dilaksanakan dalam dua Siklus. Pada Siklus I dilaksanakan selama 3 kali pertemuan begitupun dengan Siklus II jika pada siklus I siswa belum memenuhi standar kelulusan $80 \%$ dari total siswa. Adapun instrumen yang digunakan untuk memperoleh data aktivitas siswa yaitu dari lembar observasi, hasil belajar dengan pemberian pre test, post test dan tes akhir pada setiap Siklus.

\section{B. Pembahasan}

Penelitian ini berakhir pada Siklus II karena telah mencapai indikator keberhasilan. Sebelum memulai materi pelajaran dilakukan Pre Test untuk melihat kondisi awal dari hasil belajar Siswa sebelum memulai materi pelajaran. setelah selesai materi yang diajarkan dilakukan Post Test untuk melihat kondisi setelah mempelajari materi yang diajarkan. Kemudian dilakukan tes evaluasi Siklus I, dilihat dari hasil tes evaluasi Siklus I yang dilakukan masih banyak Siswa yang belum tuntas, untuk itu perlu penerapan strategi agar hasil belajar Siswa dapat meningkat, seperti diberikannya siswa hukuman kecil, diberikan soal lalu langsung dijawab atau diberi pekerjaan rumah. Dari hasil evaluasi tindakan Siklus I pada Tabel 4.17 Siswa yang dinyatakan tuntas sebanyak 22 Siswa dengan persentase $73,3 \%$ tetapi hal tersebut belum memenuhi indikator keberhasilan yaitu $80 \%$ dari siswa yang ada di kelas dan KKM yang telah ditetapkan. Untuk itu 
perlu diadakan tindakan Siklus II untuk lebih meningkatkan hasil belajar Siswa dan untuk memenuhi indikator keberhasilan yang telah ditetapkan. Dari hasil tes evaluasi tindakan Siklus II pada Tabel 4.20 Siswa yang dinyatakan tuntas sebanyak 28 Siswa dengan persentase $93,3 \%$.

Berdasarkan hasil observasi tindakan Siklus I masih banyak Siswa yang malu bertanya dan menjawab pertanyaan lisan dari Guru, selain itu Siswa masih kurang percaya diri dalam mengemukakan pendapatnya dan menjawab soal-soal yang diberikan. Kendala lain yang ada pada siklus I seperti suasana kelas yang siswanya yang ribut, hal ini dikarenakan banyak Siswa yang melakukan aktivitas diluar dari proses pembelajaran seperti menganggu teman, membahas hal lain diluar pembahasan yang diberikan oleh Guru, oleh karena itu dilakukannya tindakan tambahan agar suasana kelas kembali tenang, seperti Guru memberikan pertanyaan selipan terhadap siswa yang perilakunya sedikit susah diatur, atau memberikan gertakan seperti diancam kalau masih berperilaku kurang baik, nilainya akan rendah dan tidak tuntas. Setelah dilakukannya tindakan pada siklus I, pada tindakan Siklus II jumlah Siswa yang bertanya dan menjawab pertanyaan lisan dari Guru mulai meningkat, jumlah Siswa yang aktif dikelas juga meningkat, selain itu kegaduhan siswa di dalam kelas sudah berkurang sehingga proses belajar mengajar menjadi lancar, karena kendala yang ada pada siklus I telah diperbaiki pada siklus II.

Peningkatan hasil belajar yang terjadi dari Siklus I ke Siklus II dikarenakan model pembelajaran kooperatif dengan menggunakan strategi MURDER (Mood, Understand, Recall, Digest, Expand, Review) yang diterapkan. Model pembelajaran kooperatif dengan menggunakan strategi MURDER (Mood, Undrstand, Recall, Digest, Expand, Review) berpengaruh terhadap hasil belajar siswa dikarenakan adanya cara belajar yang baru dalam pembelajaran yang dapat menarik perhatian Siswa, seperti adanya pemberian kelompok, siswa lebih diberi kesempatan untuk menyelesaikan masalah bersama- sama, mencari penjelasan dari materi yang diberikan oleh guru dan menjawab pertanyaan bersama teman 1 kelompok, yang dimana siswa lebih bersemangat kalau mengerjakan suatu hal secara bersama-sama. Strategi pembelajaran merupakan perpaduan dari urutan kegiatan, cara mengorganisasikan materi pelajaran Siswa, peralatan dan bahan, dan waktu yang digunakan dalam proses pembelajaran untuk mencapai tujuan pembelajaran yang telah ditentukan. Pembelajaran model kooperatif dengan menggunakan strategi MURDER (Mood, Understand, Recall, Digest, Expand, Review) mendorong siswa untuk lebih termotivasi dalam belajar. Dalam penelitian ini setiap siswa secara individual belajar materi pembelajaran yang sudah dipersiapkan guru yang kemudian hasil belajar individual tersebut dibawa ke kelompok-kelompok untuk didiskusikan oleh anggota kelompok, dan semua anggota kelompok bertanggung jawab atas keseluruhan jawaban sebagai tanggung jawab bersama.

Berdasarkan hasil observasi dan hasil evaluasi selama tindakan Siklus I dan Siklus II dapat dilihat hasil belajar Siswa mengalami peningkatan setelah diterapkannya model pembelajaran kooperatif dengan menggunakan strategi MURDER (Mood, Understand, Recall, Digest, Expand, Review) pada mata pelajaran Dasar Desain Grafis kompetensi keahlian Teknik Kompuer dan Jaringan di SMK Negeri 4 Gowa.

\section{KESIMPULAN}

Berdasarkan uraian dari hasil penelitian dapat disimpulkan bahwa:

1. Presentase dari Siklus I nilai ketuntasan siswa sebesar $73,3 \%$ atau sekitar 22 siswa dan Siklus II sebesar 93,3\% atau sekitar
28 siswa, dari data hasil belajar tersebut dapat dilihat terjadi peningkatan secara berkala.

2 Implementasi model pembelajaran kooperatif dengan menggunakan strategi MURDER (Mood, Undrstand, Recall, Digest, Expand, Review) ternyata dapat meningkatkan hasil belajar siswa kelas X TKJ di SMK Negeri 4 Gowa.

\section{DAFTAR PUSTAKA}

[1] Amri, Sofan. 2014. Model Pembelajaran ARIAS Terintegratif. Jakarta:Prestasi Pustaka

[2] Aunurrahman. (2009). Pembelajaran. Bandung: Alfabeta.

[3] Astuti, Dian . 2016. Pengaruh Strategi Pembelajaran MURDER Terhadap Kemampuan Berpikir Analitis dan Hasil Belajar Pada Materi Ekologi Siswa Kelas X SMAN 16 Kab Bulukumba. Universitas Islam Negeri Makassar Djiwandono, Sri Esti Wuryani. 2012. Psikologi Pendidikan, Edisi Revisi. Jakarta: Grasindo

[4] Darmansyah. 2012. Strategi Pembelajaran Menyenangkan dengan Humor. Jakarta: Bumi Aksara

[5] Deporter, Bobby. 2008. Quantum Teaching (Mempraktekkan Quantum Learning di Ruang-Ruang Kelas). Bandung: Kaifa

[6] Eko, S. 2009. Evaluasi Program Pembelajaran. Yogyakarta: Pustaka Pelajar

[7] Hakim, Dzikrul. 2013. Penerapan Strategi Pembelajaran MURDER terhadap Hasil Belajar Siswa pada Standar Kompetensi Melakukan Pekerjaan Mekanik Dasar dikelas X SMKN 1 Cerme Gresik. Universitas Negeri Surabaya

[8] Kusnadi, Dedi. 2011. Efektivitas Penerapan Strategi Belajar MURDER dalam Menigatkan Hasil Belajar Matematika Siswa Kelas VIII Mts Negeri Model. Makassar Fakultas Tarbiyah dan Keguruan UIN

[9] Kusmariyatni. (2013). Pengaruh Model Pembelajaran Kooperatif Tipe MURDER Terhadap Prestasi Belajar Siswa Pada Mata Pelajaran IPA kelas IV di Gugus II Kecamatan Sidemen. Universitas Pendidikan Ganesha.

[10] Lamiran, Sudarmaji. 2011. Strategi Pembelajaran Sekolah Terpadu. Jakarta: PT Prestasi Pustaka Marpaung, Elisda Betharia. 2016. Pengaruh Penerapan Teknik Murder (Mood, Understand, Recall, Detect, Expand, Dan Review) dalam Kemampuan Menganalisis Unsur Intrinsik Cerpen Oleh Siswa Kelas X Sma Negeri 1 Siantar Narumonda Tahun Pembelajaran 2015/2016

[11] Nasution, S. 2004. Didaktik; Asas-asas Mengajar. Jakarta: Bumi Aksara.

[12] Rusman. 2017 . Belajar dan Pembelajaran Berorientasi Standar Proses Pendidikan. Jakarta: Kencana Prenada Media

[13] Sinar. 2018. Metode Aktive Learning: Upaya Peningkatan Keaktifan dan Hasil Belajar Siswa. Yogyakarta: Deepublish

[14] Slameto. 2010. Faktor-faktor yang mempengaruhi belajar. Jakarta: Rineka Cipta

[15] Sanjaya, Wina. 2006. Strategi Pembelajaran: Berorientasi Standar Proses Pendidikan. Jakasta: Kencana Prenada Media

[16] Siregar, E., \& Nara, H. (2007). Buku Ajar Teori Belajar dan Pembelajaran. Jakarta: Fakultas Ilmu Pendidikan, UNJ.

[17] Surya. 2014. Pakematik Strategi Pembelajan Berorientasi Standar Proses Pendidikan. Jakarta: Kencana Prenada Media

[18] Trianto. 2010. Model Pembelajaran Terpadu Jakarta: Bumi Aksara

[19] Wahab, Rohmalina. 2015. Psikologi Belajar. Jakarta: Rajawali Press

[20] Zaini, H. (2007). Strategi Pembelajaran Aktif. Yogjakarta: CTSD. 